Contending Perspectives: Curricular Reform in Economics

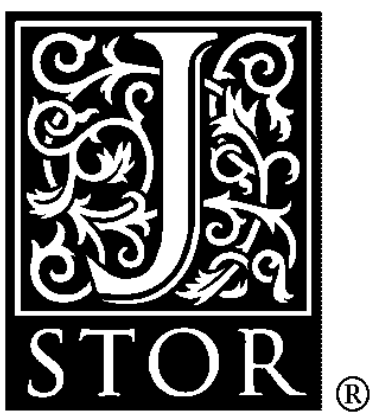

Author(s): Charles A. Barone

Source: The Journal of Economic Education, Vol. 22, No. 1 (Winter, 1991), pp. 15-26

Published by: Heldref Publications

Stable URL: http://www.jstor.org/stable/1182330

Accessed: 22/08/2008 12:28

Your use of the JSTOR archive indicates your acceptance of JSTOR's Terms and Conditions of Use, available at http://www.jstor.org/page/info/about/policies/terms.jsp. JSTOR's Terms and Conditions of Use provides, in part, that unless you have obtained prior permission, you may not download an entire issue of a journal or multiple copies of articles, and you may use content in the JSTOR archive only for your personal, non-commercial use.

Please contact the publisher regarding any further use of this work. Publisher contact information may be obtained at http://www.jstor.org/action/showPublisher?publisherCode=held.

Each copy of any part of a JSTOR transmission must contain the same copyright notice that appears on the screen or printed page of such transmission.

JSTOR is a not-for-profit organization founded in 1995 to build trusted digital archives for scholarship. We work with the scholarly community to preserve their work and the materials they rely upon, and to build a common research platform that promotes the discovery and use of these resources. For more information about JSTOR, please contact support@jstor.org. 


\section{Economic Instruction}

In this section, the Journal of Economic Education publishes articles, notes, and communications describing innovations in pedagogy, hardware, materials, and methods for treating traditional subject matter. Issues involving the way economics is taught are emphasized.

MICHAEL WATTS, Section Editor

\section{Contending Perspectives: Curricular Reform in Economics}

\section{Charles A. Barone}

The economics curriculum and the way economics is taught have changed little over the last twenty years, if economics textbooks and university catalogs are any indication. There is a sense among some economists that the discipline is too technical and narrow, that it has ignored the complexity and the larger context of economic issues and problems. ${ }^{1}$

The American Economic Association, recognizing these problems, has created a new journal, the Journal of Economic Perspectives, in an attempt to broaden the range of perspectives on economics and to show how an economic perspective can help in understanding society. This new journal is a breath of fresh air in a discipline that has become highly technical and where theoretical puzzle solving and mathematical techniques are more highly valued than having a thorough knowledge of the economy. ${ }^{2}$

Although this new journal fills a real need, it is essentially designed as a creative outlet for mainstream economists. The range of perspectives thus far has been limited, with few exceptions, to those of the neoclassical persuasion despite the much broader diversity of economic perspectives in the discipline. Radical, institutional, post-Keynesian, steady-state, and neo-Austrian are viable contemporary schools of economic thought in the United States; they

Charles A. Barone is an associate professor of economics at Dickinson College. He wishes to thank Gordon Bergsten with whom he worked closely in contending perspectives and who provided generous comments and valuable suggestions that have improved this article. He also wishes to thank Craig Houston who also provided very helpful comments. 
have a following, have active research programs, and seem to offer, at least in the eyes of their adherents, powerful insights into economic affairs. Yet in how many colleges and universities are students even given a basic introduction to heterodox economics, much less the thorough treatment accorded neoclassical economics?

Neoclassical economists act as a hegemonic force within the discipline, limiting discourse and restricting the study of economics to a single perspective. Few other disciplines in the social sciences lack such theoretical diversity. Although there are several possible explanations of just how neoclassical economics has come to define and dominate the discipline, ${ }^{3}$ the more important question here is whether this state of affairs should continue.

I will argue in this article that the time is ripe for the integration of heterodox economic theory into the mainstream of the discipline and that the potential benefits of such integration are great. I will draw on the experience at Dickinson College in Carlisle, Pennsylvania, over the last several years with an integrated economics program, which is called "Contending Perspectives in Economics," to illustrate the benefits of this integration of economic theories.

\section{NOW IS THE TIME FOR CONTENDING PERSPECTIVES IN ECONOMICS}

There are some signs that despite the drift of economics in the 1980s toward the so-called new classical economics, there is a new openness within the discipline. The mostly acrimonious exchanges between orthodox and heterodox economists during the 1960 s and 1970 s have subsided with the effective ghettoization of different perspectives. Since then, economists have been busily engaged in their own research programs with only occasional sniping across the walls separating the perspectives.

Recently, however, there has been an expanding dialogue reflecting a new openness that can be attributed in part to advances made in the field of economic methodology and perhaps the more humble assessments of the explanatory power of conventional economics in the 1980s. The creation of the new journal cited above is the result of a recognition within the mainstream that economics is too insular. Robert Highsmith and Hirschel Kasper conclude from a conference held two years ago called "Rethinking the Scope of Economics," sponsored by the Joint Council on Economics Education, that alleviating "economic problems"

depend not only upon having worthy critics and trenchant criticism but also on the opportunity for the mainstream economists to engage those critics in open, intellectual, nondefensive dialogue, where there is hope that with accepted rules of evidence, the participants and the discipline will gain greater insight into the human condition and its potential. $(1987,105)$

This is truly a great step forward, yet despite such an opening, many of the "fences" that separate the economic perspectives in economics remain, making it difficult to achieve the kind of dialogue Highsmith and Kasper envision. 
The 1980s have witnessed what A. W. Coats, in a review article, calls a "veritable flood of literature on economic methodology and on the parlous state of economics as a scientific discipline and a profession" (Coats 1986, 109). Although much of this literature comes from heterodox economists, some of it comes from within the mainstream itself. There is precious little that emerges from this literature on which to defend exclusion of perspectives.

Bruce Caldwell, a mainstreamer who specializes in economic methodology, argues quite convincingly that the only defensible stance in economics is one of "methodological pluralism" (Caldwell 1982, 250). According to Caldwell, theoretical and methodological diversity is the best way to expand our understanding of the economic world. However, as Caldwell rightly notes, that understanding can come only if we have a working knowledge of different perspectives. To achieve the sort of internal criticism that Caldwell recommends will require a different economics education than that currently offered within the discipline.

Donald McCloskey (1985), an economist of the "old" Chicago school persuasion, believes there is no ascertainable "Truth," only many partial truths dependent upon one's perspective. His work offers further evidence that entrenched positions may be softening. He argues that the use of mathematics and econometrics in neoclassical economics is little more than a rhetorical device designed to make economics appear scientific and thus more palatable. With his colleague, Arjo Klamer (1988), a radical economist, McCloskey argues that "facts and logic, narrowly defined, do not provide standards for good economic science." They view economics "as a rhetorical activity, in which economists deploy authorities, stories, and metaphors (models for instance) to persuade each other"' $(1988,2)$. This practice is seen as something positive by Klamer and McCloskey, when it is open minded and self-critical. In their view, literary criticism can play an important role in educating economists in the proper use and interpretation of rhetorical practices.

According to Klamer and McCloskey, economics requires a discursive approach, not unlike the approach recommended by Highsmith and Kasper above. Unfortunately, all too often in practice this discourse is little more than what Klamer and McCloskey call "sneering." Ideally, intellectual conversation

is a way for human beings to act together, to converse. Just as difference of endowment or taste is grounds for trade, disagreement about economics is grounds for serious conversation. Mutual respect prevents the conversation from degenerating into war. (1988)

Without underestimating the political obstacles both inside the discipline and in the larger society, ${ }^{4}$ the changes that these economists would like to see within the discipline are changes we should all take very seriously. The time is, I believe, ripe for such changes, and what better way than through curricular reform, changing the way economics is taught. Integrating heterodox perspectives into the economics curriculum will provide opportunities for us to learn different perspectives and to engage in the kinds of discourse envisioned above. 


\section{THE POTENTIAL GAINS FROM CONTENDING PERSPECTIVES}

A contending perspectives approach to economics will enrich the discipline and bring real gains to students, faculty, and the discipline. Given the different focus of heterodox theories, integrating these theories into the economics curriculum will expand the domain of economics, including the relation of economics to other aspects of human life normally excluded from conventional economic analysis (e.g., culture). When integrated within the discipline, some heterodox theories will help meet the goal of enriching the methodological basis of economics advocated by Caldwell.

Economists as a group have historically been concerned with practical, social, political, and moral issues. Their works tend to reflect both cognitive and scientific elements as well as emotive, moral, and ideological elements ( $E$. K. Hunt 1979, preface). In the comparison of different economic perspectives, the value premises of each theory become evident. By introducing contending perspectives, teachers can diversify the value premises of economics and raise the level of dialogue and understanding of the range of human values underlying human economic action and choice.

All schools of economic thought have something to offer, and integrating heterodox thought will increase our overall level of economic knowledge. Providing several paradigms in free and open contention could promote healthy competition and cooperative interchange in the pursuit of knowledge. In the absence of "sneering," a new intellectual excitement would pervade the discipline. New research would be stimulated both within perspectives and across perspectives.

Students' education in economics would be particularly affected by these changes. Obviously, learning economics from a variety of perspectives will expose them to a greater variety of economic phenomena, which should enhance their overall understanding of economics by broadening the context within which students can assess policy choices. Students would also be better able to appreciate the variety of perspectives encountered in other disciplines.

Many recognize the value of the comparative approach to education. In our own discipline, the study of comparative economic systems enhances the understanding of our own system. Likewise, the study of comparative economic theories can expand the student's knowledge of neoclassical economics as well as heterodox economics.

Teaching contending economic perspectives can also introduce a lively and healthy intellectual debate into the study of economics. Students will have the opportunity to develop evaluative skills in assessing the strengths and weaknesses of different theories. They will be better able to see the important connections between the various building blocks of theory, such as the relationship between initial assumptions and theoretical conclusions.

Finally, students will be better able to explore their own values and the values of others within the framework of scientific inquiry, learning that economic choices have moral dimensions. As a result, students will be better prepared to engage in real-world policy debates and to make more informed 
choices. Such dialogues should also contribute to individual moral and ethical development.

With respect to the possible costs of heterodox integration, perhaps the most important concern is the issue of depth vs. breadth. To the extent that the total number of economics requirements cannot be expanded and the length of courses is fixed, there is a potential trade-off here. However, the loss in time spent directly studying neoclassical economics may be offset by the enhanced understanding that comes from comparison. I believe that heterodox integration can take place in a way that minimizes if not eliminates any loss of depth within the mainstream.

A second problem is the potential for faculty strife once heterodox economics is integrated into the curriculum. This raises the familiar economic problem of destructive vs. constructive competition. Many economists would, depending upon the circumstances, argue that more competition is better than less. Although one could certainly view economics education as a market process, the fact remains that unless the current economic players consent to heterodox integration the economics market will remain unchanged.

The problem then is a political one, but one that can be anticipated and dealt with rationally. As long as heterodox integration is approached with sensitivity, I think that faculty strife can be minimized and competition can be channeled in constructive ways. Of foremost importance is the generation of a strong belief among faculty that all perspectives are important and deserve space within the discipline. Unless people are confident that their particular perspective has a more or less permanent place within the academic program, the intellectual environment will not be a positive one.

A final problem is that of faculty time and resources. Does not heterodox integration make additional demands on already scarce faculty time? The answer to this question is obviously yes, but it can be handled by reallocating our time and resources rather than by increasing our already high work loads. Crucial here is institutional support and recognition of the changed faculty/ departmental efforts that result from heterodox integration.

\section{CURRICULUM REFORM AT DICKINSON COLLEGE}

The Economics Department at Dickinson College developed an integrated economics program in 1984. Prior to this, the department was in most respects not different from other schools. The faculty was more diverse, having two heterodox economists (out of six). However, the core curriculum and general thrust of the major was in the mainstream. Unless students elected to take courses from the two heterodox economists, they were not exposed to heterodox economics. Therefore, students had no systematic exposure to different perspectives.

Integrating contending perspectives into the curriculum has taken place gradually at all levels, while maintaining a strong neoclassical core (our students spend about 80 percent of their time studying neoclassical economics). 
One new course was added to the requirements, which was offset by one fewer elective, leaving the overall number of courses unchanged.

At the introductory level, three weeks of each semester are devoted to the study of economic history and the history of economic thought. In addition to the value of this material to the study of economics (from any perspective), our purpose here is to introduce students to contending economic perspectives by exploring the historical origins of contemporary schools of thought.

Students go on to take their intermediate theory courses, including a new required course called "Contending Economic Perspectives." This course became a requirement in 1987 and introduces students to heterodox economic theories. The new course covers methodological issues and heterodox economic theories and compares and contrasts the different perspectives (see the Appendix for the course outline).

At the upper level, in all courses, faculty are required to spend a minimum of two weeks on heterodox approaches appropriate to the particular subject matter of the course. Faculty are free to select which perspectives they want their students to focus on. Finally, our senior seminars bring together various contending perspectives as a final experience for the senior major. These seminars are currently focused topically. However, we are discussing the possibility of converting them to senior thesis seminars. The thesis would provide students with the opportunity to bring together what they have learned over the course of their major program and to apply it to a particular economic problem or issue as well as to more fully develop their analytical and research skills.

The way in which we have integrated heterodox economics into the curriculum requires that students not only learn heterodox perspectives, but that they compare, contrast, and evaluate strengths and weaknesses. Our teaching emphasis is on healthy contention rather than on competition that forces clear-cut choices of one perspective over another. In some areas, paradigms overlap, offering competing explanations for the same phenomena. In other areas, paradigms focus on different aspects of economic reality and can be seen as complementary. We believe that all perspectives have something to contribute and that students can learn from all perspectives. Thus the integration of heterodox economics into the discipline goes beyond simple addition.

The implementation of this new program required a number of other changes. Although we have been able through normal attrition and the addition of one new position to diversify our faculty (four of our seven full-time equivalents [FTEs] are heterodox economists), there is no reason that faculty members cannot teach from more than one perspective. Dickinson has supported and funded three departmental faculty summer seminars for the purposes of faculty development. These seminars have covered all of the major heterodox perspectives, and faculty receive stipends comparable to summer school salaries.

Institutional support has been important for such curricular reform, because of the extra work and effort required on the part of the economics faculty. For example, untenured faculty may be reluctant to participate because it takes time away from research or other activity necessary to achieve tenure. 
In the case of tenured faculty, it may take time away from activities required for promotion. Therefore, it is important to have strong institutional support. We found our colleagues in the rest of the college very supportive of our efforts, and our reform proposal was accepted enthusiastically by the college as part of an overall program to enhance the quality of Dickinson's liberal arts education.

Initially, some faculty felt threatened by the contending perspectives proposal. We found that strengthening the neoclassical component at the same time that we were integrating heterodox economics into the curriculum helped to create unity. We chose to strengthen the quantitative dimension of the curriculum by requiring the application of statistics and calculus within the major and by requiring students to do more empirical work generally within the discipline.

\section{THE CONTENDING PERSPECTIVES EXPERIENCE}

Although our program is still in its infancy, our initial experience confirms the potential for heterodox integration. We are beginning to see evidence of the benefits for students, for faculty, and for the discipline as a whole.

Our students' response to heterodox economic theory has been overwhelmingly positive. They have found it both intellectually challenging and stimulating. There have been lively and healthy classroom discussions comparing and contrasting different perspectives. Students are developing a greater appreciation for the complexity of economic issues and problems. They are more critical and want to know how they are to choose among these contending perspectives. This, of course, has opened the door to a discussion of the nature of explanation and how to evaluate the strengths and weaknesses of a theory. The different value orientation of each theory generates discussions of values and ethical issues and their relationship to theory.

Many of the changes we are observing in our students can be understood in the context of William G. Perry, Jr.'s, stages of cognitive and ethical development $^{5}$ (Perry 1970, 1981). Perry provides a framework or taxonomy within which to understand and evaluate students' intellectual progress. Based on extensive studies of college students, Perry delineates several different levels of intellectual growth defined in terms of knowledge, values, and personal identity. The result is a conceptual hierarchy, which begins at the lowest levels where students perceive "Truth" as an absolute and authorities as holders of the Truth. Students see Truth at this level in dualistic right/wrong, either/or, black/white terms.

At more advanced levels of intellectual development, student thought is more balanced and contingent, expressing more relativistic forms of thinking. Truth becomes relative, permitting exceptions, qualifications, and inconsistencies. At this level, knowledge is relative and tied to different perspectives and values. The students' own critical abilities become paramount in the highest stage of development, both in terms of acquiring knowledge and in 
terms of dealing with personal ethical concerns, the link between thought and action. $^{6}$

Our students, as a result of heterodox integration, are showing all the signs that Perry's students exhibited as they moved from dualistic to relativistic to critical forms of thinking. ${ }^{7}$ The reasons for these developmental shifts are, of course, obvious. The changeover from a single perspective economics curriculum to one that emphasizes contending perspectives creates an educational environment much more conducive to a student's intellectual and moral development.

It should be noted that the students Perry studied did not move through these developmental stages in any mechanical, linear fashion, and many students reacted to intellectual relativism in ways that prevented them from reaching the highest level of intellectual and personal growth. Like Perry's students, ours exhibit the same variety of responses. What is noteworthy, however, is the fact that we have moved our students to a more advanced intellectual plane. As we try to understand this process more completely, our goal is to promote our students' intellectual growth more effectively in this new learning environment. We are excited about the possibilities that heterodox integration has created for us.

Although we do have little objective evidence to evaluate any changes in our students' knowledge of neoclassical economics, overall we have not noted any decline. As noted above, we have maintained a strong neoclassical core and our courses are just as rigorous. Vertical structuring demands that our students in upper-level courses apply and extend intermediate theory. We have not observed any decline in their ability to apply theory in their upperlevel courses. The inclusion of heterodox theory has for the most part taken place by limiting neoclassical breadth rather than depth. In fact, we have seen an increase in the last three years in the number of Dickinson students going on to graduate school in neoclassical economics. Furthermore, our students are coming out of the heterodox theory course with a much better overall grasp of neoclassical theory as a way of thinking. This is not surprising because one of the major thrusts of the contending perspectives course is comparing and contrasting heterodox theories with neoclassical theory. We are confident, based on our experience so far, that heterodox integration can be accomplished in ways that not only do not diminish the student's understanding of neoclassical theory but actually enhance it.

The experience for faculty has been quite positive as well. The contending perspectives faculty seminars have been very successful and provide evidence of the beneficial nature of integration for faculty. Genuine intellectual excitement has been generated as we discover new bodies of economic thought and discover that each perspective has something positive to offer. Not only have we learned other economic perspectives, but we have developed a better understanding of each other. Communication across paradigms has been enhanced and is characterized by open and nondefensive discourse, something that was previously in short supply. Sneering has all but disappeared within the department. 
The result has been an increase in the interchange among faculty. Very healthy dialogues are taking place. For example, two of our faculty from different paradigms (neoclassical and institutional) have completed a cooperative research project in yet a third paradigm (neo-Austrian) that has resulted in publication (Bellinger and Bergsten, forthcoming). Our knowledge of economic affairs and problems has grown as a result of new perspectives. These new insights have also sharpened our work within our own research programs.

If we use our experience as a microcosm of the discipline as a whole, then our initial experience with contending perspectives curricular reform seems to be consistent with the goals and expectations of Highsmith and Kasper, Caldwell, and Klamer and McCloskey discussed earlier in this article. We encourage more faculty to reexamine the scope of economics and consider contending perspectives in economics. There are other schools that are moving in this direction, such as Hobart and William Smith Colleges (Geneva, New York) and Bucknell University (Lewisburg, Pennsylvania). As more schools do so, there will be a broader experiential base upon which to build. It is hoped that some graduate schools might experiment with contending perspectives, perhaps by requiring field work in at least one heterodox theory. The discipline as a whole should then begin to show the widespread benefits of including contending economic perspectives within its method and substance.

\section{APPENDIX \\ Course Description and Outline E288-Contending Economic Perspectives}

The discipline of economics is rich in diversity and contending perspectives. This is as true today as it has been historically. Indeed, much of the current controversy over goals, methods, theoretical structures, and policy prescriptions is rooted in a fertile intellectual tradition of contending perspectives. This course is an introduction to some of the major current contending perspectives in economics. Exposure to these alternatives is essential to an understanding of today's economic issues. The currently dominant theoretical perspective in economics, the neoclassical paradigm, is useful to understand some aspects of some economic problems, but, as with other ways of seeing, it is simultaneously a way of not seeing. As you will discover as we examine the alternatives, different perspectives shed light of different intensity depending on the topic.

Textbooks

E. Ray Canterbery, The Making of Economics

Samuel Bowles and Richard Edwards, Understanding Capitalism

Herman E. Daley, Steady State Economics

William Dugger, An Alternative to Economic Retrenchment

Alfred Eichner, Towards a New Economics

Stephen Littlechild, Fallacy of the Mixed Economy

Contending Perspectives Reader

\section{Course Outline}

I. Introduction and overview

A. Why contending perspectives?

B. Background: The development of orthodox economics

1. Classical economics 
a) Background

b) Theories of man and society

(1) Liberalism

(2) Utilitarianism

c) Economic analysis

d) Policy

2. Neoclassical economics

a) Microeconomic analysis

b) Macroeconomic analysis

c) Policy

II. Heterodox economic theories

A. Marxism and radical political economy

1. Historical origins in Marx

a) Approach and method

b) Laws of motion of capitalism

c) Socialism and communism

2. Radical political economy

a) Introduction

b) Theory-core concepts

(1) Capitalism and class power

(3) Macro: Instability and growth

(4) Role of the state

c) Evaluation of American capitalism

d) The socialist alternative

B. Institutional economics

1. Overview

2. Historical origins: Veblen and Polanyi

3. Contemporary institutionalism

a) Introduction

b) Technological imperative and dual economy

c) Pecuniary imperatives and bureaucracy

d) Private-sector decentralized planning

e) Private-sector centralized planning

$f$ ) Public-sector decentralized planning

4. The overburdened economy

5. Reforming capitalism

C. Neo-Austrian economics

1. Historical origins and overview

2. Human action, competition, and market process

3. Government policy

4. Capitalist futures

D. Post-Keynesian economics

1. Introduction: Sraffa and Kalecki

2. The price mark-up

3. Stagnation

4. Stagflation and the long wave

5. Post-Keynesian economic policies

E. Steady state economics

1. Introduction

2. Core concepts

3. Fallacies of growth

4. Institutions for a steady state

III. Summary and conclusions: contrasting positions on some fundamental issues

A. Methodology

B. Human nature 
C. The nature of the good society

D. Perspectives in contention

\section{NOTES}

1. According to a very brief report, "Cracks in the Ivory Tower," in Business Week (January 15, 1990), the American Economic Association appointed a commission to "investigate widespread dissatisfaction" within the discipline. Apparently, the commission's report is a "scathing critique" of economics.

2. See the very interesting survey of recent Ph.D. graduates by David C. Colander and Arjo Klamer (1987).

3. For an institutional interpretation, see Ward (1972) and Eichner (1982). For a behavioral in terpretation, see Earl (1982). There are several radical interpretations, see Wisman (1979) and Foley (1975). For an interesting neo-Austrian interpretation made by two non-Austrian economists, see Bellinger and Bergsten (forthcoming).

4. Klamer sees this as an important obstacle, and this is one of the disagreements between him and McCloskey (Klamer and McCloskey 1988; and Klamer 1988).

5. I am grateful to my colleague, Gordon Bergsten, for bringing to my attention Perry's work in the context of this discussion.

6. My colleague, Craig Houston, has pointed out that at this penultimate stage Perry's findings are strikingly parallel to S. I. Hayakawa's work on language, thought, and action. Hayakawa makes a distinction between two-valued vs. multi-valued systems of thought and action. The human mind has a tendency to develop a two-valued perspective, which is a narrow, black-or-white, yes-or-no, right-or-wrong way appraising issues. Multivalued perspectives are associated with rational, scientific thought as well as free, open and democratic societies. Although Perry's discussion of these highest stages of intellectual and personal development differs in some specifics, there is broad consistency with Hayakawa, who in the context of semantics warns of the danger of narrow-minded thinking (Hayakawa 1964, 230-61).

7. A group of us are considering a more detailed and formal study of Perry's work and its relation to economics, education, and our contending perspectives curricular reform. This would be a long-term project and would entail formal entry and exit surveys of our economic majors.

\section{REFERENCES}

Bellinger, W., and G. Bergsten. Forthcoming. The market for economic thought: An Austrian view of neoclassical dominance. History of Political Economy.

Caldwell, B. 1982. Beyond positivism: Economic methodology in the twentieth century. Boston: Allen \& Unwin.

$$
\text { win. }
$$

Coats, A. W. 1986. Economic methodology: Theory, practice, and the current state of economics. Kyklos 39(1): 109-15.

$\rightarrow$ Colander, D. C., and A. Klamer. 1987. The making of an economist. Journal of Economic Perspectives 1:2 (Fall): 95-112.

Earl, P. E. 1982. A behavioral theory of economists' behavior. In Why economics is not yet a science, ed. A. Eichner, 90-105. Armonk, N.Y.: M. E. Sharpe.

Eichner, A. 1982. Why economics is not yet a science. In Why economics is not yet a science, ed. A. Eichner, 205-41. Armonk, N.Y.: M. E. Sharpe.

Foley, D. 1975. Problems vs. conflicts: Economic theory and ideology. American Economic Review (May): 231-36.

Hayakawa, S. I. 1964. Language in thought and action. 2d ed. New York: Harcourt.

$\rightarrow$ Highsmith, R., and H. Kasper. 1987. Rethinking the scope of economics. Journal of Economic Education 18 (Spring): 101-06.

Hunt, E. K. 1979. History of economic thought. Belmont, Calif.: Wadsworth.

Klamer, A., and D. McCloskey. 1988. The rhetoric of disagreement. Paper presented at the ASSA New York meetings. 
Klamer, A., D. N. McCloskey, R. Solow, eds. 1988. The consequences of economic rhetoric. New York: Cambridge University Press.

McCloskey, D. 1985. The rhetoric of economics. Madison: University of Wisconsin Press.

Perry, W. G., Jr. 1970. Forms of intellectual and ethical development in the college years: $A$ scheme. New York: Holt, Rinehart, Winston.

1981. Cognitive and ethical growth: The making of meaning. In The modern American college, ed. A. Chickering. San Francisco: Jossey-Bass.

Ward, B. 1972. What's wrong with economics. New York: Basic Books.

Wisman, J. 1979. Legitimation, ideology-critique, and economics. Social Research (Summer): 291-320.

\section{Advanced Placement INSTRUCTIONAL PACKAGE in Economics for High School Students FEATURES}

- Keyed to the College Board's recommended syllabus for AP Economics

- Covers all AP test content

- Focuses on student activities rather than teacher lectures

- A complete teaching and learning package, including a 400-page Instructor's Guide, with 150 lessons; 10 Student Workbooks of 175-225 pages each, with a choice of either all macroeconomics, all microeconomics, or a combination of both; the College Board's Teacher's Guide for AP economics; the Test of Understanding in College Economics.

This exciting publication gives you the program you need to fill the economics void for your Advanced Placement students.

The Advanced Placement Instructional Package (APIP) not only meets every syllabus requirement, but it prepares students for all AP economics tests. And it does it by incorporating state-of-the-art methods that focus learning on student activities rather than teacher lectures.

Advanced Placement Instructional Package (\#388) . . . . . . \$195.95/set plus $\$ 10.00$ shipping and handling.

(Indicate your choice among the 10 student workbooks,

prepackaged in sets of 5).

APIP Departmental Planning Kit (\#604)

plus $\$ 10.00$ shipping and handling.

(Includes Instructor's Guide plus a single copy of the micro- and macro-economics student manuals).

Order prepaid from the: Joint Council on Economic Education

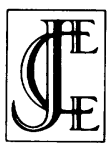
Attn: Robert Highsmith

432 Park Avenue South

New York, NY 10016

(212) 685-5499 